\title{
TECHNOLOGIES FOR EFFECTIVE DISASTER MANAGEMENT SYSTEMS: A STATE OF THE ART SURVEY OF CURRENT CHALLENGES AND OPPORTUNITIES
}

\author{
Bishwajeet Pandey \\ Gyancity Research Lab, India. \\ E-mail: gyancity@gyancity.com \\ Jason Levy \\ Gyancity Research Lab, India \\ E-mail: jlevy@hawaii.edu
}

Yousef Abubaker Mohamed Ahmed

Al-Abiary

UniSZA, Malaysia

E-mail: yousefelebiary@unisza.edu.my

\author{
Bhagwan Das \\ Department of Electronic Engineering, \\ Quaid-e-Awam University of
} Engineering, Science and Technology,

Nawabshah, Sindh, Pakistan.

E-mail: engr.bhagwandas@hotmail.com

Arifa Bhutto

Insittute of Information and

Communication Technology,

University of Sindh, Pakistan.

E-mail: arifa.bhutto@usindh.edu.pk

Arjumand Bano

Insittute of Information and

Communication Technology,

University of Sindh, Pakistan.

E-mail: arjumand@usindh.edu.pk

Recepción: 26/07/2019 Aceptación: 18/09/2019 Publicación: 06/11/2019

\section{Citación sugerida:}

Pandey, B., Levy, J., Al-Abiary, Y.A.M.A., Das, B., Bhutto, B. y Bano, A. (2019). Technologies for effective disaster management systems: a state of the art survey of current challenges and opportunities. 3C Tecnología. Glosas de innovación aplicadas a la pyme. Edición Especial, Noviembre 2019, 29-39. doi: http://dx.doi.org/10.17993/3ctecno.2019. specialissue3.29-39

\section{Suggested citation:}

Pandey, B., Levy, J., Al-Abiary, Y.A.M.A., Das, B., Bhutto, B. \& Bano, A. (2019). Technologies for effective disaster management systems: a state of the art survey of current challenges and opportunities. 3 C Tecnología. Glosas de innovación aplicadas a la pyme. Special Issue, November 2019, 29-39. doi: http://dx.doi.org/10.17993/3ctecno.2019. specialissue 3.29-39 


\section{ABSTRACT}

Disasters constitute devastating phenomena that result in the large scale loss of human life and critical infrastructure, often severely disrupting critical societal sytems and the built environment. Robust emergency management can protect human lives and ensure for resilient and resistant cities. Effective disaster management systems are essential to protect human lives and to promote the development of less brittle and vulnerable critical infrastructure systems. The use of leading edge technologies for Effective Disaster Management systems are discussed and analyzed. Early technologies for Disaster Management systems include Sirens, Amateur and Community Radio, and Short Message Services (SMS). More recent approaches inlude Satellite Radio, Information and Communication (ICT) Devices, the Internet of Things (IoTs), Big Data and Deep Learning. The strengths and weaknesses of possible solutions for Effective Disaster Management using Multi-Technologies are herein discussed. Key conclusions are highlighted to promote more efficient and effective disaster management.

\section{KEYWORDS}

Effective Disaster Management (EDM), Disaster Response, Multi-Technologies, Internet of Things (IoTs). 


\section{INTRODUCTION}

A disaster is a severe disruption that often occurs in a short span of time. Natural disasters are usually considered to constitute geological events that yield large losses to humans, natural systems or infrastructure. These natural disasters include storms (Hurricanes, Tornadoes, and Tropical), floods, Earthquakes, Wildfires and etc. In natural disasters, emergency decision makers and their respective response units initiate the disaster response and recovery phases to protect lives and critical assets. Other types of disasters are health-related, intentional and na-tech disasters. Disaster examples can include environmental pollution crises, industrial catastrophes, wars and terrorist attacks. The nature of the disaster must be considered in order to provide disaster risk reduction. Disaster risk management and sustainable hazard mitigation and resilience planning are essential. Disaster management has several definitions, as proposed by various researchers. This work focuses on Effective Disaster Management (EDM). EDM can be described as providing systems, technologies and tools to thoroughly organize and manage the information from various disciplines in order to protect human lives and critical assets and key resources. The EDM can also be well described as Effective Disaster Response (EDR). This involves responding to crises and supporting survivors after a disaster strikes. A wide number of technological tools and practices of available for EDM and EDR. EDM can offer a robust technological solution in terms of Information and Communication Technologies (ICTs) and other technologies.

\section{PREVIOUS WORK}

There are many systems, technologies and innovations that have been proposed recently for disaster management and in the recent past. Each disaster management system was designed and developed to meet specific goals and criteria. The strengths of weaknesses of these systems are now discussed below.

Spencer (2019) discusses how entertainment and leisure are related to goods and service via ICT. ICT helps to increase provide new services, products and breakthroughs for productivity growth. Spencer (2019) discussed the case of Caribbean Tourism based 
on ICT in order to market tourist destinations and attractions. This can be done by updating social media and websites to include travel advisories and visitor safety information. The information is available on social media handles using Twitter, Facebook, and Instagram for real-time updates. Lee, Park and Lee (2019) have proposed to study the implementation of citizens' adoption of digital government services.

Alazawi, Altowaijri, Mehmood and Abdljabar (2011) discussed the importance of emergency response systems. The study notes that the impact of disasters can be reduced by implementing the Telecommunications and ICT systems to reduce the human losses and as well the disruption of critical infrastructure systems. This study discusses an innovative emergency response system for disasters by capitalizing on Intelligent Transportation Systems (ITS) including VANETs (Vehicular Ad hoc Networks), mobile and Cloud computing technologies. In this way an intelligent disaster management system can be proposed. The collects information from the point of accident and generates an action plan to reduce disaster damage. In an ICT, the disaster can be controlled via Vehicular Ad hoc Networks (VANETs) as well as by Machine to Machine Communication technologies (Drake, 2009). The author also describes that in disaster management the Cloud Computing has emerged as an innovative solutions in several models of business continuity planning and disaster recovery. These ICT disaster management systems are able to collect information from different locations to make appropriate decisions. Cloud computing is a centralized system to collect and store information via server services. Users pay to avail these services instead of using, buying and installing the software or hardware (Chee \& Franklin Jr., 2010). In the Figure 1 a disaster management architecture based on different layers is put forth. This is based in part on a real-time environment and an intelligent layer to support incident response. M2M, VANET and other technologies are also are proposed to support disaster management. 


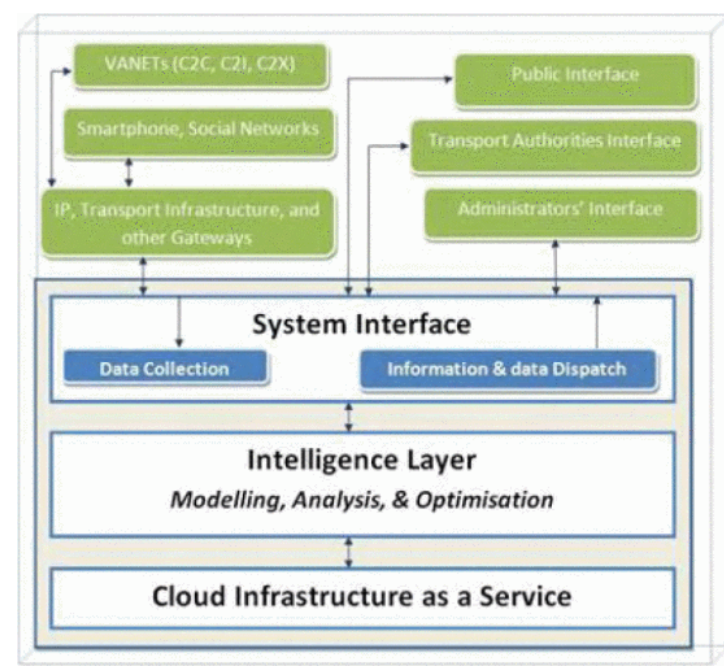

Figure 1. Disaster Management Architecture. Source: (Alazawi et al., 2011).

Islam, Sheikh, and Islam (2018) discussed a disaster management scheme based on a cognitive radio ad hoc network (GRAHN). A new solution for disaster management is provided based on a multi-layer perceptron (MLP) based disaster detection scheme. This system proposes the use of WSN and a real-time GUI to provide shared situation awareness to rescue survivors and enable better decision making.

Park et al. (2018) discuss an augmented reality (AR) based Smart Building and Town Disaster Management System. It allows for rapid guidance and supports initial response via AR. Fajardo and Oppus (2010) discussed a rescue system which was designed using an Android application known as "MyDisasterDroid". The system offers the best routes for volunteers so that they can reach the disaster zone as rapidly as possible so that the maximum number of lives can be saved. This system of disaster management is designed and developed via a Genetic Algorithm (GA) which allows for the optimization of the system by managing routes and volunteer information.

\section{MULTI-TECHNOLOGY}

This paper highlights the timely and important use of Multi-technologies for providing Effective Disaster Management. The proposed innovations can help to 
reduce the impact and likelihood of disasters in order to reduce disaster losses. Based on the information discussed above it is shown that a wide range of systems have been proposed. It is shown that the most promising solutions include GIS, mobile system, IoT based systems and Android-based approaches. ITU communications motivates researchers to use ICT systems including leading edge devices, communication systems and geospatial approaches to provide maximal safety for volunteers during a disaster and to mitigate disaster threats (Domnori, Cabri, \& Leonardi, 2011).

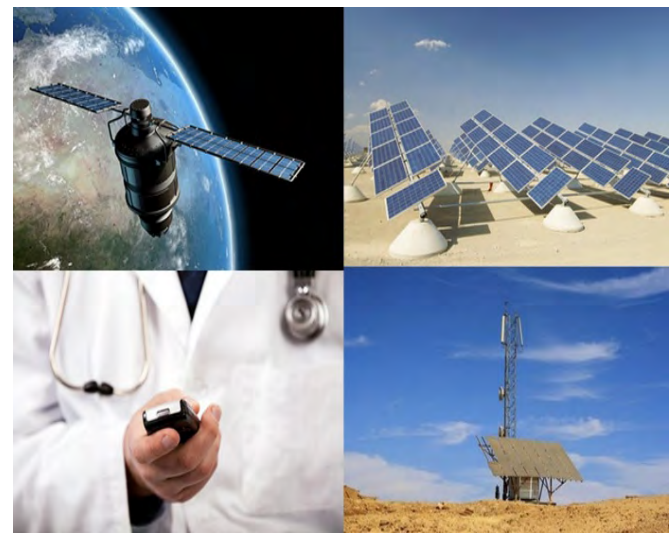

Figure 2. A Demonstration of Multi-Technologies for Disaster Management. Source: (Thomas, 2018).

A sophisticated communication system design is often used to address disaster management related issues. The phases of emergency management are shown in Figure 3.

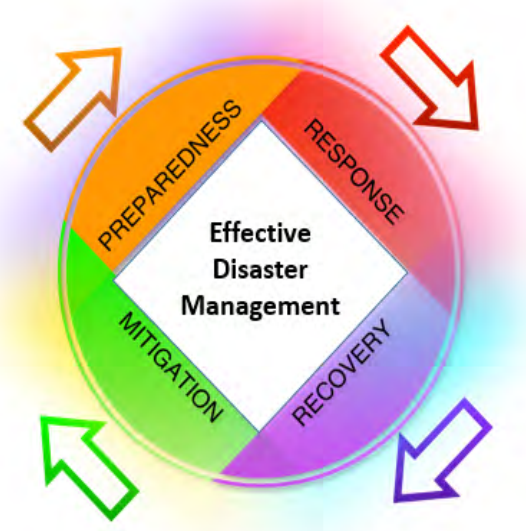

Figure 3. Multiple Phases of Effective Disaster Management. Source: (Carter, 2008). 


\section{CONCLUSION AND FUTURE SCOPE}

In this paper, the use of Multi-technologies for Effective Disaster Management systems are proposed. The Multi-Technologies include ICT, IoT and others. A multistage approach for Effective Disaster Management has been put forth. Disasters constitute an unexpected, abrupt or gradual phenomena that results in a large scale loss of human life, often disrupting critical societal sytems and the built environment. Robust emergency management and timely evacuations from the affected area can protect human lives. Effective disaster management systems are essential to protect human lives and critical infrastructure systems. A wide range of technologies for Effective Disaster Management (EDM) are put forth. The use of leading edge technologies for Effective Disaster Management systems are discussed and analyzed. Early technologies for Disaster Management systems include Sirens, Amateur and Community Radio, and Short Message Services. More recent approaches inlude Satellite Radio, Information and Communication (ICT) Devices, Internet of Things (IoTs), Big Data and others. The strengths and weaknesses of possible solutions for Effective Disaster Management using Multi-Technologies are discussed. Key conclusions are highlighted to promote more efficient and effective disaster management.

\section{REFERENCES}

Alamdar, F., Kalantari, M., \& Rajabifard, A. (2016). Towards multi-agencysensor information integration for disaster management. Computers, Environment and Urban Systems, 56, 68-85. doi: https://doi.org/10.1016/j.compenvurbsys.2015.11.005

Alazawi, Z., Altowaijri, S., Mehmood, R. \& Abdljabar, M.B. (2011, August). Intelligent disaster management system based on cloud-enabled vehicular networks. In 2011 11th International Conference on ITS Telecommunications (361-368). IEEE. 
Ali, K., Nguyen, H. X., Shah, P., Vien, Q. T., \& Ever, E. (2019). Internet of Things (IoT) Considerations, Requirements, and Architectures for Disaster Management System. In Performability in Internet of Things ( 111-125). Springer, Cham.

Banerjee, A., Basak, J., Roy, S., \& Bandyopadhyay, S. (2019). Towards a Collaborative Disaster Management Service Framework using Mobile and Web Applications: A Survey and Future Scope. In Emergency and Disaster Management: Concepts, Methodologies, Tools, and Applications ( 324-346). IGI Global.

Beydoun, G., Dascalu, S., Dominey-Howes, D., \& Sheehan, A. (2018). Disaster Management and Information Systems: Insights to Emerging Challenges. Information Systems Frontiers, 20(4), 649-652. doi: https://doi. org/10.1007/s10796-018-9871-6

Garter, W. N. (2008). Disaster management: A disaster manager's handbook. Mandaluyong City, Philippines: ADB.

Garreño, M. L., Gardona, O. D., \& Barbat, A. H. (2007). A disaster risk management performance index. Natural Hazards, 41(1), 1-20. doi: https://doi. org/10.1007/s1 1069-006-9008-y

Ghee, B.J. \& Franklin Jr., C. (2010). Cloud computing: technologies and strategies of the ubiquitous data center. CRC Press.

Comfort, L. K. (2005). Risk, security, and disaster management. Annual Review of Political Science, 8, 335-356. doi: https://doi.org/10.1146/annurev. polisci.8.081404.075608

Das, S., \& Mukhopadhyay, P. (2018). Multi-hazard disaster resilient housing with bamboo-based system. Procedia engineering, 212, 937-945. doi: https://doi. org/10.1016/j.proeng.2018.01.121

Domnori, E., Cabri, G., \& Leonardi, L. (2011, October). Multi-agent approach for disaster management. In P2P, Parallel, Grid, Cloud and Internet Computing (3PGCIC), 2011 International Conference on (311-316). IEEE. 
Drake, R. (2009). The hierarchy of emergency preparedness. In Safeguarding homeland security, 31-40. Springer, New York, NY.

Erdelj, M., Król, M., \& Natalizio, E. (2017). Wireless sensor networks and multiUAV systems for natural disaster management. Computer Networks, 124, 72-86. doi: https://doi.org/10.1016/j.comnet.2017.05.021

Fajardo, J.T. \& Oppus, G.M. (2010). A mobile disaster management system using the android technology. WSEAS Transactions on Communications, 9(6), 343-353.

Faulkner, B. (2001). Towards a framework for tourism disaster management. Tourism management, 22(2), 135-147. doi: https://doi.org/10.1016/S0261-5177(00)000480

Grossman, R. I. (2018). Disaster Management. Radiology, 288(1), 180413. doi: https://doi.org/10.1148/radiol.2018180413

Huang, G., Shen, Z., \& Mardin, R. (2019). Overview of Urban Planning and Water-Related Disaster Management. In Urban Planning and Water-related Disaster Management (1-10). Springer, Cham.

Islam, N., Sheikh, G.S. \& Islam, Z. (2018). A cognitive radio ad hoc networks based disaster management scheme with efficient spectrum management, collaboration and interoperability. arXiv preprint arXiv:1810.05090.

Janssen, M., Lee, J., Bharosa, N., \& Cresswell, A. (2010). Advances in multiagency disaster management: Key elements in disaster research. Information Systems Frontiers, 12(1), 1-7. doi: https://doi.org/10.1007/s10796-009-9176-x

Kaur, H., Gupta, S., Parkash, S., \& Thapa, R. (2018). Application of geospatial technologies for multi-hazard mapping and characterization of associated risk at local scale. Annals of GIS, 24(1), 33-46. doi: https://doi.org/10.1080/19475683. 2018.1424739 
Krishna, G. H., Chandra, V. S., Boyidi, S., Jaisankar, G., Anusha, G., Sridhar, B., ... \& Sridevi, T. (2019). Disaster Management Emergency Responsive Mechanism Using GIS and Networking with Android Technology. In Proceedings of International Conference on Remote Sensing for Disaster Management ( 729738). Springer, Cham.

Lee, T.D., Park, H. \& Lee,J. (2019). Collaborative accountability for sustainable public health: A Korean perspective on the effective use of ICT-based health risk communication. Government Information Quarterly.

Li, J., \& Zlatanova, S. (2007). Geomatics solutions for disaster management (p. 444). A. G. Fabbri (Ed.). Berlin, Heidelberg, New York: Springer.

Mukherjee, A., Dey, N., Kausar, N., Ashour, A. S., Taiar, R., \& Hassanien, A. E. (2019). A disaster management specific mobility model for flying ad-hoc network. In Emergency and Disaster Management: Concepts, Methodologies, Tools, and Applications (279-311). IGI Global.

O’Brien, G., O’Keefe, P., Rose, J., \& Wisner, B. (2006). Climate change and disaster management. Disasters, 30(1), 64-80. doi: https://doi.org/10.1111/ j.1467-9523.2006.00307.x

Oloruntoba, R., Sridharan, R., \& Davison, G. (2018). A proposed framework of key activities and processes in the preparedness and recovery phases of disaster management. Disasters, 42(3), 541-570. doi: https://doi.org/10.1111/disa.12268

Park, S., Park, S. H., Park, L. W., Park, S., Lee, S., Lee, T., ... \& Park, S. (2018). Design and Implementation of a Smart IoT Based Building and Town Disaster Management System in Smart City Infrastructure. Applied Sciences, 8(11), 2239. doi: https://doi.org/10.3390/app8112239

Prusty, A. R., \& Mohanty, A. (2019). Prospect of Low Power Sensor Network Technology in Disaster Management for Sustainable Future. In Emergency and Disaster Management: Concepts, Methodologies, Tools, and Applications ( 834-856). IGI Global. 
Spencer, A. (2019). ICT and Caribbean Tourism. In Travel and Tourism in the Caribbean (95-114). Palgrave Macmillan, Cham.

Thomas, D. S. (2018). The Role of Geographic Information Science \& Technology in Disaster Management. In Handbook of Disaster Research (311-330). Springer, Cham. 